\title{
Perceived Wealth in Bonds and Social Security and the Ricardian Equivalence Theorem: Reply to Feldstein and Buchanan
}

\section{Citation}

Barro, Robert J. 1976. Perceived wealth in bonds and social security and the Ricardian equivalence theorem: Reply to Feldstein and Buchanan. Journal of Political Economy 84(2): 343-350.

\section{Published Version}

doi:10.1086/260437

\section{Permanent link}

http://nrs.harvard.edu/urn-3:HUL.InstRepos:3612770

\section{Terms of Use}

This article was downloaded from Harvard University's DASH repository, and is made available under the terms and conditions applicable to Other Posted Material, as set forth at http:// nrs.harvard.edu/urn-3:HUL.InstRepos:dash.current.terms-of-use\#LAA

\section{Share Your Story}

The Harvard community has made this article openly available.

Please share how this access benefits you. Submit a story.

\section{Accessibility}




\title{
Reply to Feldstein and Buchanan
}

\author{
Robert J. Barro \\ University of Rochester
}

Martin Feldstein and James Buchanan have raised a number of critical points concerning my government-debt paper. For the reasons detailed below, I believe that my central thesis has not been impaired by these criticisms.

\section{Feldstein}

Feldstein's comment deals with my conclusion that government debt (and social security) will not add to net wealth in a model with operative intergenerational transfers (either from old to young or from young to old). He accepts this conclusion in the case of a static economy, but argues that it is incorrect when the economy is growing. It is important to distinguish two cases-the first in which the growth rate, $g$ (the sum of population growth and growth in real income per head), is below the steady-state (real) rate of return, $r$; and the second where $g \geq r^{1}$ The first case is straightforward and turns out to require no modifications to my previous results. Feldstein's contrary conclusion is the result of an error in calculating present values of future tax liabilities. The second case is both more interesting and more difficult, and I present some analysis of it below.

Suppose that the economy is in a steady state with output growing at rate $g$. The (real) rate of return is constant and equal to $r$. Consider, first, the case in which $r>g$. In this situation Feldstein (pp. 333-334) considers the impact of government debt that grows at rate $g$, so that the ratio of debt to income remains constant over time. ${ }^{2}$ He argues, ". . . some

${ }^{1}$ Feldstein also deals with a third case where the gross-of-tax rate of return is above $g$, but the net-of-tax rate is below $g$. Since the main purpose of this case is to make more plausible the situation where $g$ is at least as large as the net rate of return, it is not necessary for me to deal with it separately.

2 The limitation of the steady-state growth rate of the public debt to $g$ can be rationalized by assuming that the value of the outstanding stock of debt at any point in time is bounded by the government's collateral, which I assume can be measured by the present value of future taxing capacity. If taxes are limited to a fraction, $\tau$, of national income, $y$, then the present value, calculated at the current date $t$, of future taxing capacity is $\tau y(t) /(r-g)=\tau y(0) e^{g t} /(r-g)$. Hence, the government's collateral grows at rate $g$ and is finite for any $t$ if $r>g$. If government debt grew at a rate faster than $g$, then the outstanding stock would eventually exceed the government's collateral. 
future taxes would have to be levied to limit the growth of the government debt. ... For example, if ... the debt grow[s] at the rate of growth of the economy, taxes will be required to finance only the fraction $[1-g / r]$ of future interest payments" (p. 332). The last statement is correct but does not imply his conclusion that "only in the special case of a static economy $(g=0)$ is the present value of required future taxes equal to the present value of the debt itself" (p. 333). The fallacy is that the fraction, $(1-g / r)$, applies to a base that is larger (increasingly over time) than it would have been if the debt had remained constant rather than growing at rate $g$.

Consider an initial debt issue of amount $B(0)$ and a path of subsequent issues that make the outstanding stock of debt grow at rate $g$. Hence, $B(t)=B(0) \mathrm{e}^{g t}$, and the amount of debt finance at any date $t>0$ is $d B / d t=g B(t)$. Taxes levied at date $t$ are the amount needed to finance interest payments net of debt finance, $r B(t)-g B(t)$. The present value of these future taxes, discounted at rate $r$, is

$$
\int_{0}^{\infty}(r-g) B(t) \mathrm{e}^{-r t} d t=(r-g) B(0) \int_{0}^{\infty} e^{-(r-g) t} d t=B(0) .
$$

Hence, as would be expected, the present value of the future taxes coincides with the amount of the initial debt issue for any growth rate $g$ (as long as $g<r$ ). Therefore, the presence of growth in the economy (at a rate below $r$ ) leaves unchanged the conclusion that government bonds are not net wealth.

Consider, now, the second case where $r \leq g$. (The situation with $r<g$ in a steady state implies inefficient capital overaccumulation, as discussed in Phelps [1966].) In this case it is possible to finance all of the future interest payments without incurring any future taxes by having the debt grow forever ${ }^{3}$ at rate $r .{ }^{4}$ In this situation, where $r \leq g$ in a steady state, it appears that debt issue would be regarded as net wealth and would therefore raise aggregate demand. Further, it seems that a sufficient amount of debt issue would cause enough of a shift from saving to consumption so that the steady-state rate of return would be raised to (just) exceed the growth rate.

${ }^{3}$ In one respect this possibility hinges on an infinite horizon-any finite truncation (corresponding, say, to a fixed date for the end of the world or to an exogenous liquidation date for the debt) would restore equality between the present value of taxes and the amount of initial debt. On the other hand, an individual's effective horizon for capitalizing taxes would also not be infinite if intergenerational transfers were not (expected to be) operative for some generations far in the future. In this sense it is the relative values of the horizons for the world and the individual that are important, rather than whether either is infinite. A further consideration, pointed out by Starrett (1970), is that the end of the world, if it is anticipated, is presumably stochastic. Starrett argues (p. 709) that a stochastic end of the world is equivalent to an infinite horizon with an appropriate specification of the discount rate applied to future utilities.

${ }^{4}$ The debt could also grow at rates above $r$ to finance a continuing flow of transfer payments. The government's collateral, as calculated in $n .2$ above, is now infinite. 
The important issue is whether the economy would ever be in a steady state where $r \leq g$. The reason that government debt issue can move the economy out of this situation is that the government's collateral, which grows at rate $g$ over an infinite horizon (see n. 2), allows the debt to expand forever at rates at least equal to $r$. Are there any private individuals or institutions that would have a similar capacity and incentive in the absence of government intervention? In the overlapping-generations models of Diamond (1965) and Cass and Yaari (1967), there are no economic units with a sufficiently long time perspective to engage in this type of activity, so that a competitive equilibrium with $r \leq g$ in a steady state is possible. On the other hand, in a model of a utility-maximizing immortal family, as in Sidrauski (1967), the solution with $r \leq g$ in a steady state would be untenable. In this situation the family would be motivated to play the same game as the government by issuing debts in exchange for current consumption, financing these debts by allowing them to grow at a rate at least equal to $r$ but not higher than $g$-a rate that would not exceed the growth rate of the family's collateral-and thereby never reducing future consumption. ${ }^{5}$ Hence, a competitive equilibrium would have to be in the (efficient) region where $r>g$ in a steady state. In a situation with finite-lived individuals, it seems that operative intergenerational transfers would play an equivalent role. In particular, when $r \leq g$ in a steady state, transfer payments from young to old (which I referred to as arising from a "gift motive" in my earlier paper) that grow at a rate at least equal to $r$ but not higher than $g$ would be feasible-in the sense that the ratio of transfers to income would not grow over time-and would raise at least the present consumption level without reducing any future levels of consumption. ${ }^{6}$ It seems that the operation of these types of transfers would insure that a competitive equilibrium is in the (efficient) region where $r>g$ in a steady state. My main hesitancy about this conclusion is that I have been unable to demonstrate that the transfer scheme, which can feasibly raise the consumption level of all family members (living in finite time) if $r \leq g$, would be consistent with utility maximization as viewed by each family member separately. (Hopefully, Brock and Scheinkman, well-known experts on the economics of infinity, will provide a final resolution of this question.) Accordingly, at this point I cannot rigorously rule out the existence of the case, $r \leq g$, in which debt issue would raise net wealth. Nevertheless, I

5 Thompson (1967, p. 1205) claims that a corporate firm, which has an infinite legal life, would be motivated to carry out similar policies. However, I cannot see why this policy is generally feasible, since the firm's collateral would not automatically grow at rate $g$; presumably, its net earnings are not a fixed fraction of national income.

${ }^{6}$ Reductions of bequests from old to young would have an equivalent effect, but it seems that bequests would not be operative in a steady state where $r \leq g$, at least if bequests are motivated solely by concern for the utility of descendants (and assuming preference for a unit of own consumption over that of a descendant, starting at equal values of consumption per head). 
would be surprised if many advocates of standard fiscal policy would be happy to rest the argument for the efficacy of such policy on the possible existence of this case.

Finally, Feldstein observes near the end of his comment that the effect of government bond issue on future generations is complicated and is therefore likely to be neglected by current generations. It is plausible that computational difficulties would add to individual uncertainty, and the model could be usefully supplemented to make that uncertainty explicit. However, it is much less clear that this complication would imply systematic errors in a direction such that public debt issue raises aggregate demand. One could argue at the same level of rigor that government deficits make people sufficiently nervous to reduce their consumption demand when taxes are replaced by public debt issue. As a general point it is difficult to identify a substitute for rational behavior as a basis for forming predictions in theoretical models.

\section{Buchanan}

Buchanan begins his comment by pointing out my failure to acknowledge an intellectual debt to David Ricardo. I readily accept this criticism, although it has no substantive bearing on my results.

I should indicate, first, that my analysis was directed toward fiscal operations that involve shifts between tax and debt finance for a given volume of public expenditures. Shifts in the expenditure level have real effects that depend on the degree of substitutability between public and private expenditures in individual utility functions (Bailey 1971, chap. 9) and on the direct productivity of public expenditures (Grossman and Lucas 1974), and it did not seem necessary to become involved in these issues.

Concerning a public debt issue that corresponds to either a transfer payment or a lump-sum tax cut, Buchanan states, “. . p persons who purchase these bonds must draw down private investments or reduce private consumption." This assertion is incorrect since, as a matter of a budget constraint, the (representative) individual can use the full amount of his transfer payment (tax reduction) to just purchase the bonds; the issue is whether, in fact, individuals will be motivated to save the full amount of their increased disposable resources. Buchanan then says, “. . . it is impossible that 'the increase in $B$ [bonds] implies a one-to-one increase in the asset supply ..." " and later "... the government bonds will replace private bonds or other assets." In fact, private debt issues are not replaced because of any direct budget-constraint requirements, but rather will be crowded out if the public debt issue leads to an excess supply of earning assets (at initial interest rates) and therefore to an increase in interest rates. An excess supply results if individuals do not respond to the debt 
issue by saving (in the form of government bonds) the full amount of the transfer payment (tax cut). The one-to-one increase in saving (demand for bonds) arises if the future tax liabilities implied by the government debt are fully capitalized, so that perceived wealth is unchanged and individuals therefore maintain the same level of consumption demand. Hence, Buchanan's statement that "... this neglects the possible effects of the sale of bonds on displaced private borrowers" does not make sense. If government bonds are not perceived as net wealth, then the demand for bonds rises one-to-one with the supply, there is no change in interest rates, and no displaced private borrowers.

The basic analysis can be extended to view government bonds and future tax liabilities as two elements in a larger household balance sheet with imperfect substitutability among the variety of assets and liabilities (because of differences in characteristics of risk and "liquidity," etc.). In this context the demand for bonds would rise one-to-one with the supply (in the case of a "helicopter drop" of bonds) only if the bonds and the associated capitalized tax liabilities were perfect substitutes. ${ }^{7}$ More generally, one could consider the different risk and liquidity characteristics of bonds and the tax liabilities, and also bring in "imperfect" private capital markets (as I did in a preliminary way in Sections II-IV of my paper). The implications of these considerations for the net effect of public debt issue on aggregate demand hinge on such issues as whether the government or the private economy is more efficient at the margin in producing liquidity services or carrying out loans, and on how closely (uncertain) individual tax liabilities are correlated with individual incomes. There is no presumption from this extended theoretical analysis that bond-financed tax reductions (transfer payments) would increase aggregate demand.

Buchanan briefly discusses empirical evidence on whether future tax obligations are capitalized. He cites Feldstein's (1974) study of social security as evidence to the contrary. Feldstein's main conclusion (p. 920) is that the "... effect of social security is to reduce personal saving by half of what it otherwise would be." In fact, Feldstein's results (p. 917) show a significant effect of a "social security wealth variable" (which seems to measure primarily changes in the fraction of workers covered by social security and secondarily shifts in age structure) on consumption only when the years 1929-40 are added to the 1947-71 sample, suggesting that the variable may be operating principally as a dummy for the pre1937 years for which it takes on a zero value. Further, the effect of the social security variable over the entire sample $(1929-40,1947-71)$ is

\footnotetext{
${ }^{7}$ In the sense that individuals were concerned only with the difference between the amount of government bonds and the amount of capitalized tax liabilities in their portfolios.
} 
insignificant when an unemployment variable is included. ${ }^{8}$ Accordingly, Feldstein's finding that social security has drastically reduced saving and capital accumulation must be regarded as highly tentative.

Some support for the view that future taxes are capitalized is presented in empirical studies of consumption and saving behavior by Tanner (1970), Kochin (1974), and David and Scadding (1974).

Finally, Buchanan (p. 340) adds the weight of his own casual observation to the empirical issue: ". . . the behavior of legislators seems to offer indirect evidence against the capitalization hypothesis. Can anyone in the post-Keynesian world of 1975 seriously question the proclivity of politicians to expand public debt in preference to tax increases?" This hypothesis may be a bit loose to submit to empirical testing, but it is hard to reconcile it, in a general way, with the post-World War II behavior of the federal government. The quantity of U.S. government debt that is privately held (excluding holdings of the Federal Reserve, social security trust fund, etc.) was ${ }^{9} \$ 204$ billion at the end of 1947 and $\$ 230$ billion at the end of 1970-implying an average annual growth rate of 0.5 percent per year. On the other hand, U.S. government tax receipts (including other receipts like social security payments) rose from $\$ 43$ billion in 1947 to $\$ 192$ billion in 1970 - an average annual growth rate of 6.5 percent per year. (If federal politicians had a "proclivity ... to expand public debt in preference to tax increases" over this period, it was more than matched by a "declivity" of the public.) Despite the modest growth of privately held public debt, the ratio of federal expenditures to GNP rose from 13 percent in 1947 to 21 percent in 1970. Hence, the ready availability of debt finance is apparently not a necessary accompaniment to increases in the share of output absorbed by the federal government. Since 1970 there has been a faster growth rate of public debt- to $\$ 271$ billion at the end of 1974, implying a 4.1 percent average annual growth rate from 1970 to 1974 . Over this period, taxes rose to $\$ 291$ billion, implying a 10.4 percent average annual growth rate of taxes from 1970 to 1974. Hence, even in the most recent period, taxes grew faster than the stock of privately held federal government debt. Further, the fraction of GNP accounted for by federal spending was almost constant from 1970 to 1974, suggesting that an acceleration of public debt is not a sufficient indicator of a rising share of government spending in total output. ${ }^{10}$

${ }^{8}$ For further discussion of these results, see Upton (1975).

${ }^{9}$ All data are from Council of Economic Advisers, Economic Report of the President, 1975 and earlier issues.

${ }^{10}$ This note is a convenient place to correct some typographical errors in my original paper. The date references to Patinkin's book on pp. 1096, 1116, and 1117 should be 1965 . On p. 1099, the $A_{2}^{0}$ in equation (3) should be $A_{1}^{0}$. The $A_{1}^{0}$ 's that appear two and eight lines below this equation should be $A_{i}^{0}$. 


\section{References}

Bailey, M. National Income and the Price Level. 2d ed. New York: McGraw-Hill, 1971.

Cass, D., and Yaari, M. "Individual Saving, Aggregate Capital Accumulation, and Efficient Growth." In Essays on the Theory of Optimal Economic Growth, edited by K. Shell. Cambridge, Mass.: M.I.T. Press, 1967.

$\rightarrow$ David, P., and Scadding, J. "Private Savings: Ultrarationality, Aggregation, and 'Dennison's Law."' J.P.E. 82, no. 2 (March/April 1974): 225-49.

Diamond, P. "National Debt in a Neoclassical Growth Model." A.E.R. 55 (December 1965): 1126-50.

$\rightarrow$ Feldstein, M. "Social Security, Induced Retirement, and Aggregate Capital Accumulation." J.P.E. 82, no. 5 (September/October 1974): 905-26.

Grossman, H., and Lucas, R. F. "The Macroeconomic Effects of Productive Public Expenditures." Manchester School 42 (June 1974): 162-70.

Kochin, L. "Are Future Taxes Anticipated by Consumers." J. Money, Credit and Banking 6 (August 1974): 385-94.

Phelps, E. "An Essay in Dynamical Efficiency." In Golden Rules of Economic Growth. New York: Norton, 1966.

Sidrauski, M. "Rational Choice and Patterns of Growth in a Monetary Economy." A.E.R. Proc. 57 (May 1967): 534-44.

Starrett, D. "The Efficiency of Competitive Programs." Econometrica 38 (September 1970): 704-11.

Tanner, J. E. "Empirical Evidence on the Short-Run Real Balance Effect in Canada." J. Money, Credit and Banking 2 (November 1970): 473-85.

Thompson, E. "Debt Instruments in Macroeconomic and Capital Theory." A.E.R. 67 (December 1967): 1196-1210.

$\rightarrow$ Upton, C. Review of A. Munnell, The Effect of Social Security on Personal Saving. J.P.E. 83, no. 5 (October 1975): 1090-92. 